Dziś każda poważna refleksja dotycząca powiązania teologii i polityki musi kształtować swoją strukturę w odniesieniu do dwojakiego rodzaju działania. Po pierwsze, takiego, które jednocześnie łączy i oddziela przemyślenia Jacoba Taubesa i Carla Schmitta. Po drugie, takiego, które pomija paradygmat teologiczno-polityczny poprzez uduchowienie materialnego świata, strącając go w niebyt. Taki mistyczny sposób rozumienia wspólnej płaszczyzny teologii i polityki prowadzi do deprecjonowania „heretyckiej” tradycji wiążącej Thomasa Münzera z refleksją marksistowską oraz marksistowską tradycję materialistyczną z latynoamerykańską teologią wyzwolenia. Tej radykalnej, materialistyczno-teologicznej tradycji, w różnych miejscach i czasach zawsze towarzyszyły rozmaite formy rewolucji. Chodzi tu więc o tradycję uciśnionych i niewidocznych. W tym „znaku czasu” mamy do czynienia z tym, co Walter Benjamin nazywa Jetztzeit („czas-teraz") ${ }^{1}$. To, co uciśnione i ukryte (Jetztzeit), jest eksplozją mocy wielości. Ponadto, utożsamienie tego, co uciśnione i ukryte w historii, jest siłą wykraczającą poza logikę i granice imperium, tworzącą nieutopijne, efektywne i rzeczywiste projekty oporu, walk i wyzwolenia (exodus)².

1 Zob. W. Benjamin, O pojęciu historii, tłum. A. Lipszyc, [w:] tegoż, Konstelacje, Kraków 2012, s. 311-323 [wszystkie przypisy pochodzą od tłumacza].

2 Pojęcie „exodusu” rozwijają Hardt i Negri w Rzecz-pospolitej: A. Negri, M. Hardt, Rzecz-pospolita: poza wtasność prywatna i dobro publiczne, tłum. Praktyka 
Celem analizy wspólnego pola teologii i polityki jest podążenie śladami logiki tego, co niewidoczne i uciśnione. Musimy zatem przede wszystkim przyjąć perspektywę tradycji łączącej teologię z rewolucją i rozważyć „heretycką” możliwość materialistycznej teologii politycznej, w której teologię i polityczność łączy aparat pojęciowy, będący podstawą obu tych pól badawczych. Co więcej, kluczowe dla tego nowego pola badawczego będą takie pojęcia, jak podmiotowość, wydarzenie, produkcja, exodus, czy proroctwo. Rozmawiamy o tym z Tonim Negrim przy okazji mającego się niedługo ukazać angielskiego tłumaczenia jego książki Factory of Strategy: Thirty-three Lessons on Lenin ${ }^{3}$.

GABRIELE FADINI: Wspomnieliśmy o Thomasie Münzerze i wojnie chłopskiej z 1525 roku. Marks określił ją jako jedno z najważniejszych rewolucyjnych wydarzeń $w$ historii Niemiec. Faktycznie filozofowie od Engelsa ${ }^{4}$ do Blocha ${ }^{5}$ pojmowali rewolucję Münzera jako prototyp marksistowskich, materialistycznych intuicji; $\mathrm{w}$ istocie, ukazała ona wewnętrzną prawdę teorii komunizmu. A ta „wewnętrzna prawda” teorii materialistycznej jest blisko związana z teologią (jako że Münzer był przede wszystkim teologiem). Dlatego też teologia może być postrzegana jako element składowy procesu rewolucyjnego, nawet jeśli na ogół jej się w ten sposób nie rozumie. Przykładem tego jest właśnie Thomas Münzer i jego polityczna teologia rewolucji, a bardziej współcześnie, niektórzy z jego „spadkobierców”, jak choćby Camilo Torres ${ }^{6}$ i ruch teologii wyzwolenia, kontynuujący wyzwoleńczą walkę w Ameryce Łacińskiej i tym samym ukierunkowujący naszą refleksję w stronę wspomnianych wątków. Jakie są Pana przemyślenia odnośnie tej tradycji? ANTONIO NEGRI: Czasami pewien rodzaj teologii współwystępuje z wydarzeniami rewolucyjnymi. Należy jednak jasno określić, o jakiej

Teoretyczna, Kraków 2012. Pisze o nim także Fadini: G. Fadini, Ontological Resistance: A Meditation on Exodus and Power, thum. C. Davis, "Angelaki: Journal of the Theoretical Humanities" 2007, vol. 12, no. 1, s. 61-72.

3 Zob. A. Negri, Factory of Strategy: Thirty-three Lessons on Lenin, tłum. A. Bove, New York 2014.

4 Zob. F. Engels, Postęp reformy spotecznej na kontynencie, tłum. E. Werfel, [w:] MED, t. 1, Warszawa 1960, s. 738, oraz tegoż, Wojna chtopska w Niemczech, [w:] MED, t. 7, 1963, s. 385-486.

5 Zob. E. Bloch, Thomas Münzer als Theologe der Revolution, Leipzig 1989 (pierwsze wydanie 1921).

6 Zob. Z.M. Kowalewski, Guerilla latynoamerykańska, Warszawa 1978, s. 205-208. 
teologii tu mówimy. Nie wszystkie teologie, co oczywiste, są związane ze zjawiskami rewolucyjnymi, a nawet wprost przeciwnie - istnieją teologie, które wchodzą w bliskie relacje z ich przeciwieństwem, czyli czystą, ideologiczną reprodukcją Imperium. Teologia staje się ważna dla rewolucyjnego myślenia, kiedy bezwarunkowa miłość (agape i amor) uznaje się za niczym nieograniczoną siłę - gdzie, innymi słowy, sam logos, racjonalność podporządkowuje się miłości (amor). ${ }^{7} \mathrm{Z}$ tego punktu widzenia amor ma przede wszystkim epistemologiczne, ale również soteriologiczne znaczenie. Oznacza to, że właśnie miłość kształtuje moce i siły mogące rozwijać dobro wspólne i poprzez dobro wspólne przynosi jeszcze więcej agape. Ta epistemologiczna moc miłości łączona jest z mocą wyzwolenia. Wyzwolenie jawi się tu jako radykalny materializm, skupiający się początkowo na soteriologii i przechodzący do rewolucji totalnej. W tym sensie, koniecznością staje się zrozumienie relacji: agape i ubóstwo, amor i ubóstwo - czyli związku między teologią i historią oraz teologią i polityką.

Mamy tu do czynienia z przynajmniej dwoma kierunkami. Zgodnie z pierwszym, ubóstwo utożsamiane jest $\mathrm{z}$ władzą, a istnienie relacji między teologią a polityką jest możliwe, gdyż ubóstwo jest zdolnością wyrażania różnych form miłości (amor), kierowania namiętności, a w końcu - wyrażania pragnienia. Druga droga ukazuje ubóstwo jako sytuację rozpaczliwą, z której może nas uratować jedynie transcendencja. Jasne jest, że tylko pierwsza koncepcja ubóstwa może sprawić, że miłość (amor) przyjmie wymiar praktyczny. Innymi słowy, tylko niemistyczne rozumienie ubóstwa może nadać miłości (amor) znaczenie polityczne.

Mistycyzm w rzeczywistości odziera ubóstwo ze wszystkiego, redukując je do nędzy. Definiując je wyłącznie w kategoriach duchowych w relacji do boskości, neutralizuje moc i pragnienie właściwe ubóstwu. Taka zresztą jest rola religii. Natomiast teologia wyzwolenia jest próbą przeciwstawienia historycznej koncepcji ubóstwa, rozumianej jako zdolność buntowania się, duchowej wyłącznie i obojętnej idei religii - lub ściślej, logosu. Pojęcie ubóstwa rozwijającego się poprzez miłość (amor) zakłada powszechną otwartość i dyspozycję ku wspólnotowości, a także przemieszczenia wytworzonych dóbr w czasie i przestrzeni. Ubóstwo w takim rozumieniu jest alternatywną dynamiką życia, przeciwstawną zamkniętej tożsamości z interpretacji ubóstwa w kategoriach duchowych.

7 Zob. M. Hardt, L. Schwartz, A Conversation with Michael Hardt on the Politics of Love, "Interval(le)s" 2008/2009, http://www.cipa.ulg.ac.be/interval les4/73_shwartz.pdf.

Innymi słowy, tylko niemistyczne rozumienie ubóstwa może nadać miłości (amor) znaczenie polityczne 
Komunizm Münzera opiera się na wcieleniu jako zasadzie immanencji, co oznacza, że źródłem prawa nie jest hierarchiczna teokracja, ale prawo natury, zgodnie z którym „Chrystus” jest takim samym „,źródłem stworzenia” boskości, jak cała rzeczywistość i wieczność wraz z doczesnością. Zasadą oporu i walki z grzechem - czyli przeciwko tym, którzy chcą wziąć w posiadanie to, co zostało dane wszystkim - jest uczestniczenie w ruchu immanencji, którym jest Chrystus - wskazany przez Pana logos. „Pustka”, o której mówi niemiecki mistycyzm ${ }^{8}$, staje się u Münzera pustką Boga, który, stając się człowiekiem, wzywa ludzi do czynienia Boga9. Tworzona przez tę pustkę podmiotowość jest płaszczyzną immanencji boskiej obecności w historii. Polityczną teologią rewolucji - lub oporu. Tu nasuwa się na myśl postać [Dietricha] Bonhoeffera, który pojmował teologię jako proces przekształcania transcendencji w moc immanencji. ${ }^{10}$

Odpowiedź na to teologiczne pytanie znajdujemy w ludzkich rozważaniach kwestii nieskończoności i doskonałości. Ludzie zaczynają stawiać to pytanie nie tyle w obliczu mistycznej czy wewnętrznej pustki, lecz w obliczu próżni doświadczenia i pustki czasu - kiedy to zatrzymuje się i znów rusza do przodu. Wygnana z ziemskiego raju ludzkość znajduje się na krawędzi pustki niebytu, przeciw której musi nieustannie tworzyć byt, żeby kontynuować ten proces. To właśnie w obliczu tej niezwykle ryzykownej pustki ludzkość musi funkcjonować, aby być.

Powstaje pytanie: czy można określić płaszczyznę immanencji jako skonstruowany plan? Innymi słowy, czy myśl teologiczna, jako transcendentna, może zostać podporządkowana myśli życia poddanej żywotnym siłom immanentnym w jego produkcji? Lub, z drugiej strony: czy myśl teologiczna, jako transcendentna, może ograniczyć się wyłącznie do transcendencji czasu - ostatniej z form transcendencji - której doświadcza podmiot stojący przed pustką i jej ruiną? Wierzę, że jedyną możliwą teologią jest ta, która uznaje podporządkowanie transcendencji immanencji. I w ten sposób teologia staje się nośnikiem bardzo silnej, pozytywnej możliwości! Możliwości, która jednak pozostaje

8 Zob. P. Augustyniak, Istnienie jest Bogiem, ja jest grzechem: rozprawa o teologii niemieckiej, mistrzu Eckharcie, Lutrze, wolnych duchach i boskiej woli, Warszawa 2013.

9 Nieco odmienną interpretację logiki przekształcenia ludzkości w Boga prezentują Žižek i Milbank, zob. rozdz. 1 i 3 w: S. Žižek, J. Milbank, The Monstrosity of Christ: Dialectic or Paradox?, red. C. Davis, Cambridge MA 2009.

10 Zob. D. Bonhoeffer, Ethics, tłum. N.H. Smith, New York 1955; tegoż, Letters and Papers from Prison, tłum. E. Bethge, New York 1967. 
otwarta na sukces lub porażkę: ryzyko niepowodzenia i alternatywy, ryzyko eksperymentowania, czyli nie ryzyko Sartre'a czy Augustyna, ale ryzyko absolutnie realistyczne i niedające się nigdy wykluczyć. Ryzyko, w którym nigdy nie zachodzi zależność „aut-aut” [lub-lub], ale zawsze „et-et” [i-i]. W tym kontekście, jak sądzę, powinniśmy ponownie przemyśleć Münzera, odsunąwszy na bok historyczne fałszerstwa, z perspektywy których był on często interpretowany. Z drugiej strony, wymiar grzechu i zła można zrozumieć wyłącznie w oparciu o określone ramy teologii moralnej.

Zło i grzech stanowią antytezę rozumienia radykalnego otwarcia miłości (amor). Co więcej, zło i grzech są w zasadzie przeszkodą w tym, co z Michaelem Hardtem nazywamy „treningiem miłości” ${ }^{11}$, czyli konstytutywnego i powszechnego elementu życia. Mówiąc ściślej, zło jest blokadą tego, co społeczne; negacją zdolności ekspresji. Określane jest nie samo przez się, lecz w relacji do swojego przeciwieństwa.

W tym kontekście rozwiązaniem problemu zła nie jest ani powrót do złożoności egzystencji, ani nawet jej przywrócenie. Przykładowo, u Hölderlina czy Hegla, zło było zawsze definiowane zarówno jako blokada pragnienia, jak i przełamanie blokady. Zawsze było interpretowane w kategoriach przywrócenia pierwotnej kondycji, domniemanej całości bytu. Zło jest karą, brakiem; dobro zaś jest powrotem, czy też przywróceniem działania całości Wszystkich. Żadne odtworzenie nie może być jednak przywróceniem, ponieważ ludzkość, pochłonięta przez rozwijające się przeciw wszelkim przeszkodom (które nazywamy złem) dobro, zmienia się i podlega ciągłej, nieustannej transformacji. Dobro wspólne buduje się w oparciu o agape, nie jest więc ono rzeczywistością dopuszczającą proste odtworzenie minionych czynów. To raczej życie zbudowane na miłości jest rzeczywistością, która wykorzystuje niekończący się proces - proces, który ciągle się zmienia i pozyskuje energię z bogactwa pojedynczych, krzyżujących się z nim implikacji. Dobro, nieskończoność, nie są niczym więcej, jak czystą konstrukcją. Odważmy się mieć nadzieję, odważmy się coś zbudować!

\section{Jednak proroctwo...}

Wyobraźnia rozwija się w kategoriach proroczych poprzez podążanie za rozwijającą rzeczywistość tendencją epistemiczną. Tendencja ta nie jest jednak gotową drogą, ponieważ może rozwinąć się na więcej niż tylko dwie ścieżki (czy nawet kilka ścieżek). To proces nieustannie podlegający zmianom: telos nigdy nie może zostać uchwycony, jest

11 Zob. M. Hardt, A. Negri, Rzecz-pospolita..., s. 284-294.

Mówiąc ściślej, zło jest blokadą tego, co społeczne; negacją zdolności ekspresji. Określane jest nie samo przez się, lecz w relacji do swojego przeciwieństwa 
w ciągłym ruchu. Nie ma pewności pragnienia czy proroctwa i nie ma nieuchronnego przeznaczenia. Właściwie pragnienie to nic innego, jak swego rodzaju „w sobie”, które napotyka nieskończone możliwości określające to, co najbardziej prawdopodobne, gdy utrzymują się warunki produkcji wymyślonej hipotezy.

Proroctwo jest czymś na kształt absolutnego ryzyka, będąc jednocześnie wiedzą i działaniem, które próbuje interpretować powszechną formalność procesu. Innymi słowy, proroctwo jest próbą odkrycia wspólnej formy, która nie zobowiązywałaby do ruchu, ale raczej mieściła w sobie pragnienie wspólnego działania. Proroctwo jest więc dystopijne - jest hipotezą zmieniającą się poprzez modyfikację warun-

Agape zaś jest praktyką, która we wspólnocie dóbr i bogactw stanowi walkę o odzyskanie dobra wspólnego,

przeciwko wywłaszczeniu pracy i produkcji ków, w których się narodziła. Proroctwo żyje w napięciu; nigdy nie jest dialektyczne, jest wciąż powtarzającym się od nowa procesem. Jednocześnie napięcie ożywiające proroctwo jest konstytutywnie sprzeczne, ponieważ właściwie nie buduje świata, ale w procesie budowy nieustannie weryfikuje samo siebie w obliczu sił, które rzeczywiście go tworzą. Proroctwo dzieli dynamikę pragnienia - tak naprawdę nie jest pragnieniem tworzącym rzeczywistość, ale tą częścią pragnienia, która kieruje praktyką w celu skutecznego wznoszenia rzeczywistości. W tym ujęciu proroctwo jest zatem przewidywaniem i weryfikacją praktyki.

I tu wracamy do ważnego punktu historii rewolucji. Rewolucja Münzera przebiega wzdłuż konkretych determinant czasowych. Jest afirmacją Jetzt nieredukowalną do tego, co pochłania czas, będąc otwartą na konstytutywną praktykę wieczności. To wieczność, której sercem jest praktyka agape. Agape zaś jest praktyką, która we wspólnocie dóbr i bogactw stanowi walkę o odzyskanie dobra wspólnego, przeciwko wywłaszczeniu pracy i produkcji. Jest powtarzaniem aktu kenozy (opróżniania), ale również powstaniem nowej, konstytutywnej praktyki. W książce Kairòs, Alma Venus, Multitudo mówię o miłości (amor) jako praktyce dobra wspólnego, a przede wszystkim o kairòs jako Chrystusie, który uniża samego siebie, aby stworzyć nowy byt ${ }^{12}$. Tu pojawia się natychmiast pytanie: czy może to być paradoksalna zbieżność materializmu i teologii?

Paradoks ten w dużym stopniu określa naszą sytuację, jakby tocząc się w nieskończoność: kairòs, Jeztzeit zdają się nie znajdować innego rozwiązania poza tym paradoksem, tj. w ożywiającym go nierozwiązywalnym napięciu. Jednak nie można poprzestać tylko na samym paradoksie. Musi on zostać przekroczony w konstytutywnym działaniu,

12 Zob. A. Negri, Kairòs, Alma Venus, Multitudo, [w:] tegoż, Time For Revolution, tłum. M. Mandarini, New York 2003. 
jakim jest miłość (amor). I tu pojawia się kluczowe pytanie: w jaki sposób amor może przekroczyć paradoks natychmiastowości, paradoks Jetzt [teraz], zachowując moc daru i ekspresji (innymi słowy, doświadczenie nowego obecne w Jetzt)? Odpowiadając na to pytanie, trzeba myśleć w kategoriach akumulacji i progu, dostrzegać za pojęciem miłości (amor), jak i za każdym Jetzt, nie podmiot jako jednostkę, ale podmiot określony już jako dobro wspólne, będący częścią wspólnoty. Tylko w ten sposób możliwe jest wydobycie dyskursu z diachronicznej ekstensjonalności będącej swego rodzaju przerwą (lub wzmocnionym wyrażeniem negacji), która zmienia się w dostatek, nadmiar nie będący rezultatem totalnej, analogicznej, produktywnej przyczyny. Tylko jeśli siła ta nie zostanie sprowadzona do dialektycznego kołysania się między akumulacją i progiem, może zmienić współrzędne relacji między miłością (amor) i ubóstwem - relacji, w której akumulacja pragnień nieodłącznych ubóstwu nie tylko czyni zeń moc wieczności, ale radykalnie zmienia samą jego strukturę. Chodzi tu nie o przejście z ilości w jakość, o którym mówili starzy marksiści, ale o niedarwinowską złożoność elementów miłości (amor) i oporu, akumulacji i innowacji, która zakłada, że dobro wspólne nie jest banalną podstawą tożsamości, ale gwarancją potencjalnego splotu miłości i ubóstwa.

Jednym z tematów, które coraz częściej pojawiają się w Pańskich ostatnich tekstach, jest exodus. Nie jest on ruchem w przestrzeni, lecz ruchem „konstytuowania” - w znaczeniu odzyskania i wyzwolenia. Pojęcie to porzuca $w$ ten sposób swoją historyczną konotację na rzecz figury wydarzenia obecnego $\mathrm{w}$ każdej praktyce oraz walce wyzwoleńczej. Nieprzypadkowo teologia wyzwolenia mówi o doświadczeniu exodusu jako „całkowitym wyzwoleniu”, które odrzuca wszelki język reformistyczny i zakłada konieczność radykalnego obalenia opresyjnego systemu.

Kiedy mówimy o exodusie, mówimy przede wszystkim o rozłamie w społecznych i gospodarczych strukturach rzeczywistości. Pojęcie exodusu zakorzenione jest w prawdziwym stwierdzeniu, że kapitalizm jest już pokonany, a zatem klasa robotnicza (siła robocza), wielość nie zostanie już nigdy więcej zgromadzona pod sztandarem kapitału. Exodus jest więc mechanizmem czysto podmiotowym. Horyzontem, który zakwestionował kapitalizm. Jest zakwestionowaniem porządku kapitalistycznego, gdyż będąc podporządkowanym prawom kapitalizmu, zobowiązany jest pozostawać i działać zgodnie z ustanowionymi regułami i ograniczeniami. Wydarzenie exodusu ma więc swój początek w tych obiektywnych warunkach. 
Istnieją dwie alternatywy dla postawy wytwarzającej exodus. Pierwszą z nich jest front jednolitego kapitału. Jest jasne, jak już powiedzieliśmy powyżej, że napotyka on stanowczy opór ze strony konstytutywnej mocy exodusu. Druga postawa jest nie mniej adekwatna, jednak ryzykowna dla części tzw. radykałów - jest to pozycja reformistyczna. Byliśmy już świadkami jej porażki. Na przykład w latach sześćdziesiątych i siedemdziesiątych dwudziestego wieku organizowano i wdrażano programy reformistyczne, jednak zasadniczą wadą tej postawy było przekonanie, iż cel, do którego zmierza, jest oczywisty, nawet zanim jeszcze postawiony zostanie pierwszy krok. To czysta iluzja; w rzeczywistości w exodusie istnieje wyrwa, przez którą można przejść, ścieżka, po której można kroczyć, nie znając określonego celu podróży. Natomiast stanowisko reformistyczne stwarza pozory, iż wie, jaki kierunek obierze rewolucja. Postawa exodusu jest znacznie bardziej otwarta i radykalna. W czasie exodusu, przeznaczenie jest przedmiotem wyobraźni, wszystko tworzy się od nowa.

Także zauważam w tym punkcie wiele podobieństw z teologią wyzwolenia, choć istnieją też inne aspekty, z którymi nie potrafię się utożsamić. Poruszając się wśród terminologii rewolucyjnej, sytuacji wiecznego exodusu, potrzebuję formy „wiary”, by zbudować model dobra wspólnego, dzięki któremu wraz z innymi stanę się częścią całości, by wspólnie budować przejścia, które pozwolą mi wykuć nowe wymiary przyszłości i nadchodzącego świata miłości.

W tym miejscu trzeba jednak być precyzyjnym. W idei exodusu zawiera się bowiem odrzucenie dialektyki, wszystkich warunków transcendentalnych, Trójcy Świętej i idei nicejskich (w istocie, to właśnie w Nicei wymyślona została nowoczesną dialektyka!). Exodus jest opartym na całkowitym i absolutnym ryzyku konstytutywnym urządzeniem, ponieważ wychodzi od materialnie określonego warunku, mianowicie faktu, że człowiek nie jest już niczyim niewolnikiem. W exodusie zdolność wytwórcza, zdolność wyrażania potrzeb, realizowania pragnień, staje się całkowicie autonomiczna.

Exodus w teologii wyzwolenia uosabia się w konieczności „stawania się świadomym” - tj. radykalnej afirmacji autonomicznej podmiotowości. Ruch wyzwolenia nie tylko jest oparty na upodmiotowieniu, ale jest wyzwoleniem przede wszystkim samych podmiotów, ich ciał, pragnień i namiętności. Exodus w teologii wyzwolenia wyróżnia ta jednostkowość. Dlatego też wydaje mi się krzyżować z Leninem. Sądzę, że nieredukowalna teza Pana książki Factory of Strategy dotyczy roli podmiotowości, nie tylko w rozwoju 
procesu rewolucyjnego, ale także jako śladu nieciagłości i rozłamu w tym samym procesie. Nieprzypadkowo w swoich notatkach zatytułowanych roboczo Marksizm o państwie Lenin łączy „mesjanizm” z pytaniem: „kto powinien zacząć?”13. Oczywiście nie Mesjasz, a rosyjski proletariat, jest jednak pewna pośrednia zbieżność w kwestii podmiotu między mesjanizmem a rewolucją.

Moja książka poświęcona Leninowi była próbą odczytania go na nowo. Stawia ona autora książki Państwo a rewolucja w kontekście ruchu, w którym idea partii jest ufundowana na pojęciu awangardy. Pomysł był prosty: zdestabilizować kapitalistyczną władzę opartą na czynnikach ekonomicznych i społecznych, po czym zrestrukturyzować ją w perspektywie walki klas. Dotyczy to wykładu poświęconego postaci Lenina, który połączył historię ruchu robotniczego i nowe polityczne dążenia robotników masowych. Wykład ten rozwinął głębszą rzeczywistość restrukturyzacji kapitalizmu.

Do tej pory dominowało przywiązanie do leninizmu w znaczeniu funkcjonalnym i przejściowym, jak gdyby był on dziedzictwem, które ruch robotniczy musi zrealizować, by przejść do kolejnych stadiów, w których relacja między technicznym (i materialnym) składem klasowym a składem politycznym uległa całkowitemu przekształceniu z robotnika masowego do społecznego. Lenin, ojciec tego ruchu, musi zostać ponownie umieszczony w obrębie technicznego składu klasowego. Fundamentalne żądania Lenina są aktualne (możliwe do zrealizowania), jednak muszą one być umieszczone w kontekście nowych uwarunkowań politycznych i ekonomicznych walki klasowej. Teza mojej książki była bliska tej, którą sformułował Mario Tronti w swoim tekście Lenin in Inghilterra potem przetłumaczonej i zmienionej na Lenin w Nowym Yorku ${ }^{14}$ Jest to wzór i projekt, który oznaczał zarówno czerpanie z przeszłości, jak i nie-dialektyczne pęknięcie w kierunku przyszłości konfliktu klasowego.

Musimy zawsze pamiętać, że exodus występuje w ryzykownym kontekście. W pewnych fazach przekształcania świata exodus jest bezsprzecznie figurą czasową, ale też i przestrzenną. Dziś, w czasach zmiany, pytamy nie tyle o to „kto powinien zacząć?”, ale o to „kto powinien skończyć?”, lub nawet „kto i gdzie w czasach globalizacji będzie organizować walkę komunistyczną?”.

13 Zob. W.I. Lenin, Państwo a rewolucja, [w:] tegoż, Dzieta wszystkie, t. 33, Warszawa 1987.

14 M. Tronti, Lenin in England, [w:] Working Class Autonomy and the Crisis, red. Red Notes, London 1979. 
Obecnie nasz problem dotyczy projektu, który - w sytuacji określonej przez koniec unilateralizmu ukształtuje i urzeczywistni politycznie pierwszy projekt wyjścia z kapitalizmu. Choć staram się tego unikać, moje myśli często wracają do Europy, gdzie dostrzegam możliwość realizacji mechanizmu „exodus - zmiana - spełnienie na najwyższym stopniu rozwoju", a nie, przykładowo, w Ameryce Łacińskiej, czy Chinach. Mówiąc o spełnieniu, mówię oczywiście o spełnieniu całkowicie pozbawionym Mesjasza rozwiązującego ten problem. Wolę myśleć o mesjanizmie jako zbiorowej i immanentnej logice, którą można odnaleźć w rozwijającej się wielości.

Lenin nadal jest i zawsze będzie dla nas obrazem wielości. W istocie Lenin potęguje dla nas istniejącą wielość. 
ANTONIO NEGRI (1933) - włoski filozof i działacz polityczny, wykładał m.in. na Uniwersytecie w Padwie, École Normale Supérieure w Paryżu oraz Université de Paris VIII. W latach sześćdziesiątych i siedemdziesiątych brał czynny udział w działaniach na rzecz włoskiego ruchu robotniczego (jako współzałożyciel Potere Operaio i Autonomia Operaia Organizzata). W roku 1979 roku został osadzony w więzieniu jako podejrzany o współudział w porwaniu i zamordowaniu przez Czerwone Brygady premiera Włoch, Aldo Moro. W roku 1983 opuścił więzienie dzięki mandatowi poselskiemu i wkrótce zbiegł do Francji. Po powrocie do Włoch, w latach 1997-2003 dokończył odbywanie skróconej kary. Autor m.in. Marx oltre Marx : quaderno di lavoro sui Grundrisse (1979), Les Nouveaux espaces de liberté (1985, wspólnie z Félixem Guattarim), Il lavoro di Giobbe: il famoso testo biblico come parabola del lavoro umano (1990), Powrót. Alfabet biopolityczny (2002, polskie wydanie 2006, rozmowa z Anne Dufourmentelle), Goodbye Mr Socialism (2006, polskie wydanie 2008, rozmowa z Rafą „Vavolim” Scelsim), In Praise of the Common (2009, razem z Cesarem Casarino) oraz czterech książek napisanych wspólnie z Michaelem Hardtem: Labor of Dionysus: a Critique of the State-form (1994), Imperium (2000, polskie wydanie 2005), Multitude: War and Democracy in the Age of Empire (2004), Commonwealth (2009, polskie wydanie 2012)

\section{Cytowanie:}

A. Negri, G. Fadini, Materializm i teologia, „Praktyka Teoretyczna” nr 8/2013, http://www.praktykateoretyczna.pl/PT_nr8_2013_Teologie_emancypacyjne/03.Negri.pdf (dostęp dzień miesiąc rok)

Słowa kluczowe: Włodzimierz Lenin, Jacob Taubes, Carl Schmitt, Thomas Müntzer, niemiecki mistycyzm, materializm, teologia wyzwolenia, immanencja 